\title{
Slovenian Complementary Health Insurance as a Service of General Economic Interest
}

\author{
Bruno Nikolić \\ University of Ljubljana, Faculty of Administration, Slovenia \\ bruno.nikolic@fu.uni-lj.si
}

\begin{abstract}
Slovenian legislation defines complementary health insurance as an activity of the public interest, which represents an inseparable and essential element of healthcare system and as such pursues objectives identical to those of compulsory health insurance - financial security of population against high healthcare expenses and appropriate and fair access to efficient and quality healthcare. EU Member States often introduce different regulatory measures to safeguard the public interest in the field of economic activities. These measures often contravene the Union acquis (the rules on the functioning of the internal market and competition (aw), which is in principle unacceptable. This article aims to define Slovenian complementary health insurance as a service of general economic interest, which opens up new prospects for the Member States' adoption of the regulatory measures that are not compliant with the rules on the functioning of the internal market and EU competition law.
\end{abstract}

Keywords: financing of healthcare, complementary health insurance, service of general economic interest (SCEI), public interest

$J E L: K 32$

\section{Introduction}

Health insurance is insurance against financial loss which is incurred by illness, body injury and birth or death of the insured person. Individuals with health insurance are provided with social security against uncertainty that may befall them if an insured event occurs. Some countries organize health insurance at a systemic - national level and finance their healthcare system through pre-paid Health insurance contributions. Such a system can be found in Slovenia, where healthcare system is financed by two sources, that is public and private funds. The lion's share, around $75 \%$ of these funds, represents social or compulsory health insurance. ${ }^{1}$ The largest source of private financing represents voluntary health insurance (a little above $50 \%$ of private funds),

1 The remaining public sources are budgetary resources of the state and the municipalities.

Nikolić, B. (2015). Slovenian Complementary Health Insurance as a Service of General Economic Interest. 
of which complementary health insurance represents more than 90\% (ZZZS, 2013, 144; SURS, 2013). ${ }^{2}$

Healthcare is a fundamental component of European welfare state. Although EU Member States regulate this area differently, all regulations have a common feature of pursuing the universal access to healthcare, which is based on the principle of solidarity. When Member States join the EU, they confer the exercising of a part of their sovereign rights to the EU. In other words, they renounce a part of their competences and pass them, to a greater or lesser extent, on the EU institutions. In the early period of the development of the European Economic Community, the field of healthcare fell within the exclusive competence of the Member States. The Treaty of Rome, which entered into force in 1958, did not visibly affect the field of healthcare. ${ }^{3}$ Development of the European Economic Community and later the EU has, over time, thoroughly blurred the lines between national legal systems of Member States and EU law. This is reflected in the area of healthcare as well. EU's interest in healthcare has been on the increase, which is evident from the erosion of Member States' competence in this field. ${ }^{4}$ The leading role in this have the reforms of the Founding Treaties, secondary legislation, the development of interpretation of fundamental principles and progressive role of the Court of Justice of the European Union. ${ }^{5}$ Member States also do not have complete autonomy in organizing the healthcare financing system. Their autonomy mainly depends on the organizational structure of financing system and on its legal regime. Member States often introduce different regulatory measures in order to protect the public interest regarding financing of healthcare system and provisions of medical services. These measures often cross the autonomy threshold admissible by EU law, which classifies as an infringement of Union acquis. ${ }^{6}$

2 The remaining private sources are direct payments for health services made by individuals (around $44 \%$ of private funds) and donations of various charities and other donors.

3 Healthcare and health, especially in terms of its protection, were mentioned only by three Articles: 36, 48(3) and 56(1).

4 Van de Gronden (2013, p. 128) writes about Europeanisation in the field of providing and organizing social services of general interest. The term Europeanisation is also used by Szyszczak (2013, p. 321) in order to explain the emergence of new networks of established, and new players, creating the concept of social services of general interest and the emergence of the Commission with a new governance competence and capacity in the form of soft law and soft governance processes.

5 For detailed discussion on the development of EU law influence on social services from the beginning of integration until the Lisbon Treaty see Damjanovic \& de Witte B. (2009).

6 Slovenian complementary health insurance has already been a subject of infringement proceedings before the Court of Justice of the European Union. In its action against the Republic of Slovenia, the European Commission accused it of Infringement of Article 8(3) of First Council Directive 73/239/EEC (First non-life insurance Directive) and of Articles 29 and 39 of Council Directive 92/49/EEC (Third non-life insurance Directive) - Infringement of Articles 56 and 63 of TFEU (Judgement of the CJEU case C-185/11 of 26 January 2012, Par. 19). With regard to the infringement of Article 8(3) of First non-life insurance Directive and Articles 29 and 39 of Third non-life insurance Directive, the Court of Justice of the European Union ruled that, by incorrect and incomplete transposition of First and Third non-life insurance Directive into national law, the Republic of Slovenia has failed to fulfil its obligations under Article 8(3) of First non-life insurance Directive and Articles 29 and 39 od Third non-life insurance Directive (Judgement of the CJEU case C-185/11 of 26 January 2012, Рar. 27). With regard to the infringement of Articles 56 and 63 of TFEU, the Court of Justice of the European Union 
Legal regulation of healthcare, including the healthcare financing system, is, within the meaning of the Union acquis, substantially influenced by the concept of Service of General Interest - SGI. Definition of individual segments of healthcare in the context of service of general interest under certain conditions excludes the scope of the internal market rules and EU competition law (non-economic services of general interest) or justifies the Member States' regulatory measures that do not comply with the rules on the functioning of the internal market and EU competition law (services of general economic interest). This article aims to define Slovenian complementary health insurance as a service of general economic interest, which opens up new prospects for the Member States' autonomous regulation and allows the adoption of the regulatory measures that are not compliant with the rules on the functioning of the internal market and EU competition law. Such definition enables national legislature to adopt regulatory measures in the public interest, which reinforce the social dimension of healthcare financing.

\section{The Concept of Service of General Interest}

\subsection{Services of General Interest}

Services of general interest, also known as public services, are legal concept covering a series of different activities. These include large network industries, such as energy industry, telecommunications, traffic, audio-visual and postal services, education, water supply, waste management and, last but not least, healthcare and social services. These services are essential for the daily life of citizens and enterprises, and reflect Europe's model of society. They play a major role in ensuring social, economic and territorial cohesion throughout the Union and are vital for the sustainable development of the EU in terms of higher levels of employment, social inclusion, economic growth and environmental quality (European Commission, 2007, p. 3). Services of general economic interest can be further defined as services of an economic natureservices of general economic interest and services of a non-economic nature - non-economic services of general interest.

\subsection{Non-Economic Services of General Interest}

Non-economic services of general interest (non-economic public services) include the following activities: tax system, the police, the judiciary, social security systems etc. Member States have exclusive competence over these

dismissed the action. Its decision is based on the finding that there is no coherency between the summary of allegations claiming that the Republic of Slovenia violates Articles 56 and 63 of TEFU and the statement of claim in the context of which the European Commission accuses Slovenia of incorrect and incomplete transposing of First and Third non-life insurance Directive (Judgement of the ECJ case C-185/11 of 26 January 2012, Par. 30). The Court of Justice of the European Union rejected the complaint as inadmissible, meaning that it did not decide on the merits of the case. This means that the European Commission can once again bring an action against Slovenia and with appropriate supplement of the complaint achieve hearing on the merits of the case. 


\section{Bruno Nikolić}

activities, which are not, within the meaning of the Union acquis, subject to EU competition law and the rules governing the functioning of the internal market (European Commission, 2007, 4; Article 2 of the Protocol No. 26 on services of general economic interest, annexed to the Lisbon Treaty (2007/C 306/01)). Over time, the scope of activities defined as non-economic services of general interest has been constantly diminishing and thus simultaneously reducing Member States' autonomy in this field. European Commission plays a key role in this, as its "soft law" approach (non-binding legal acts) broadens the scope of European legislation (Neergard, 2013, p. 209).

\subsection{Services of General Economic Interest}

The concept of services of general economic interest refers to market services for which the Member States, for general interest reasons, determine special obligations for providing public services. These include activities provided by large network industries (telecommunications, postal services, electricity, gas, traffic etc.) and other services of general economic interest (waste management, drinking water supply, radio and television broadcasting service etc.) (Pečarič \& Bugarič, 2011, p. 166). Services of general economic interest are considered in nearly every segment of the Union acquis. Their definition is to be found in primary legislation, specifically in the Treaty on the Functioning of the European Union (hereinafter referred to as TFEU) and Protocol No. 26 on services of general interest, annexed to the Treaty of Lisbon. Article 106(2) of the Treaty states that undertakings entrusted with the operation of services of general economic interest or having the character of a revenue-producing monopoly are subject to the rules contained in the Treaty, in particular to the rules on competition, in so far as the application of these rules does not obstruct, in law or in fact, the performance of the tasks entrusted. This should however not affect the development of trade to such an extent as would be contrary to the interests of the Union (European Commission, 2011, Раг. 3).

Beside primary legislation, services of general economic interest are regulated also by secondary legislation. The most important of them is Directive on Services in the internal market. ${ }^{7}$ The majority of secondary legal sources concerning the field of services of general economic interest is the reflection of the liberalisation policy of the EU, which was implemented by a so-called sectoral approach. It enabled the European Commission to regulate the specifications of individual services of general economic interest (the fields of energy industry, telecommunications, traffic and other network-bound economic activities) by means of various secondary legislative acts (Brezovnik, 2008, p. 40). ${ }^{8}$

7 Directive 2006/123/EC of the European Parliament and of the Council of 12 December 2006 on services in the internal market (OG L 376/37, 27 December 2006).

8 Directive 96/92/EC of the European Parliament and of the Council of 19 June 1996 concerning common rules for the internal market in electricity (OG L 027, 30 January 1997); Directive 97/67/EC of the European Parliament and of the Council of 15 December 1997 on common rules for the development of the internal market of Community postal services and the improvement of quality of service (OG L 15, 21 January 1998); Directive 2002/22/EC of the 
In addition to primary and secondary law, the institutions and other EU bodies influence services of general economic interest also through other forms of binding and non-binding legal acts. ${ }^{9}$

Despite the extensive literature concerning services of general economic interest and considerable efforts for their exact definition by all three EU branches of government, which is reflected in numerous acts from this field, a clear-cut legal definition of this concept has yet to be determined.

\subsection{Social Services of General Interest}

Another important concept in the field of healthcare is the concept of social services of general interest - SSGI. ${ }^{10}$ This term is not defined by neither primary nor secondary law. It is the latest concept in the group of services of general interest which cannot be found in binding European legislation. The political agenda first mentions it in the European Commission's report on the European Council session in Laeken - Services of General Interest from 2001. In legal context it is first found in a non-binding Commission communication titled Implementing the Community Lisbon programme: Social Services of General Interest in the European Union, ${ }^{11}$ which in addition to health services in narrower sense ${ }^{12}$ defines two main categories of social services (included compulsory and complementary health insurances). ${ }^{13}$

This Communication further states that social services of general interest do not constitute a legally distinct category within EU law. ${ }^{14}$ Social services of general interest in legal terms qualify as, depending on the nature of their activity, services of general economic interest or non-economic services of general interest. The mere fact that the activity is considered a social activity does not mean that it cannot be simultaneously considered as an economic

European Parliament and of the Council of 7 March 2002 on universal service and users' rights relating to electronic communications networks and services (Universal Service Directive) (EU Official Journal L 108 of 24 April 2002); Directive 97/33/EC of the European Parliament and of the Council of 30 June 1997 on interconnection in Telecommunications with regard to ensuring universal service and interoperability through application of the principles of Open Network Provision (EU Official Journal L 199 of 26 July 1997) etc.

9 To illustrate, here are a few examples: Commission Green Paper on Services of General Interest, Brussels, 21 May 2003, COM(2003) 270 final; Communication from the Commission: White Paper on Services of General Interest, Brussels, 12 May 2004, COM(2004) 374 final; European Parliament Resolution of 5 July 2011 on the future of social services of general interest (2009/2222(INI)); European Parliament Resolution of 14 March 2007 on social services of general interest in the European Union (2006/2134(INI)); Examples: case C-393/92, Almelo, [1993], case C-320/91, Corbeau, [1993], case C-340/99, TNT Traco, [2001], case C-393/92, Almelo, [1993], case C-475/99, Ambulanz Glöckner, [2001], case C-41/90, Höfner and Elser, [1991], case C-266/96, Corsica Ferries, [1998]...

10 For detailed development and better understanding and differentiation of all concepts of general interest see Neergaard (2013).

11 Communication of the Commission: Implementing the Community Lisbon programme: Social Services of General Interest in the European Union (COM(2006) 177 of 26 April 2006).

12 They are not covered by this Communication.

13 More precisely in the first category: "statutory and complementary social security schemes, organised in various ways (mutual or occupational organisations), covering the main risks of life, such as those linked to health, ageing, occupational accidents, unemployment, retirement and disability".

14 This view is shared by Szyszczak (2013). 


\section{Bruno Nikolić}

activity. Social services of general interest, which have an economic nature, are classified as services of general economic interest (European Commission, 2010, p. 17). They have to assure the compatibility of their organisational arrangements with rules on the internal market and EU competition law. ${ }^{15}$

Figure 1: The scope of EU law

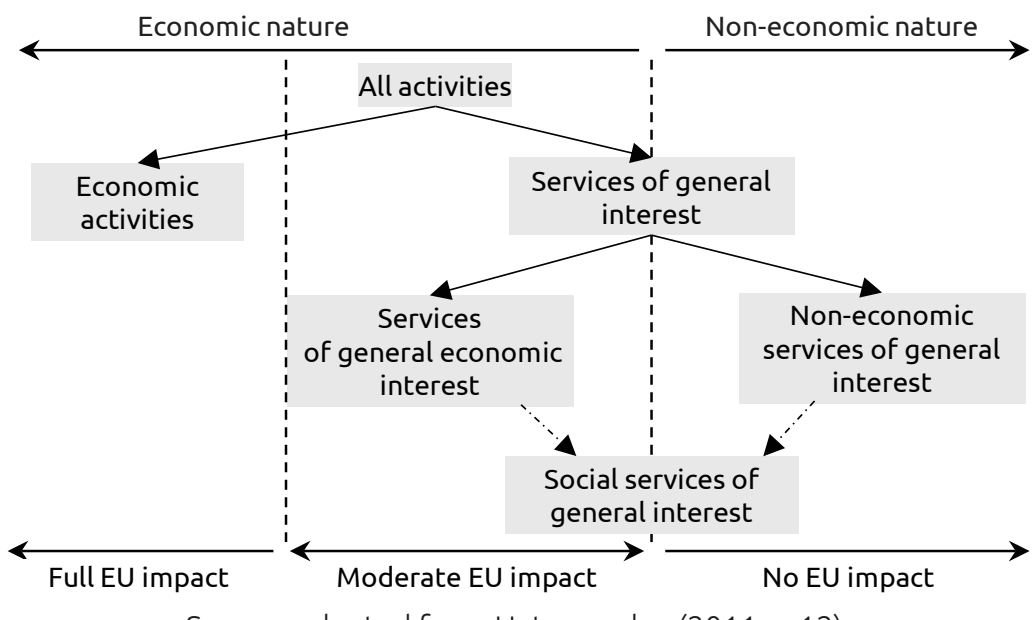

Source: adapted from Hatzopoulos (2011, p.12).

\section{Competences and Criteria for Defining the Activity of Complementary Health Insurance as a Service of General Economic Interest}

Services of general economic interest are different from ordinary services in that public authorities consider that they need to be provided even where the market may not have sufficient incentives to do so. This is not to deny that in many cases the market will be the best mechanism for providing such services. However, if the public authorities consider that certain services are in the general interest and market forces may not result in a satisfactory provision, they can lay down a number of specific service provisions to meet these needs in the form of service of general interest obligations (European Commission, 2001, point 14).

The first condition for defining an activity as a service of general economic interest is its economic nature. The second condition requires that the activity provides services (goods) that are of existential importance for the society, which therefore considers that provision of these services (goods) is of general interest and subjects them to a special legal regime.

15 Neergaard (2013, pp. 207-210) illustrates the relations between services of general interest services of general economic interest (or non-economic services of general interest) and social services of general interest with family ties between grandmother, mother and granddaughter. 
When defining an activity as a service of general economic interest within the meaning of European legislation, an important question should be considered, namely that of distribution of competences between Member States and the EU. When defining a service of general economic interest, Member States have a wide discretion, which is supported by both, primary and secondary EU law, as well as the Court of justice of the European Union case-law. Nowhere in the Union acquis a specific definition of the term services of general economic interest can be found, nor the conditions that need to be fulfilled so that a Member State could refer to the existence and protection of a special legal regime of service of general economic interest. ${ }^{16}$ Beside the absence of the definition, EU law does not grant any special powers to the EU regarding the services of general economic interest. Thus in the case BUPA the Court of justice of the European Union took a position that defining an activity as a service of general economic interest falls under Member States' competence. ${ }^{17}$ This refers even more for services of general economic interest which have the nature of social or healthcare services, as Member States have almost exclusive competence in this area. ${ }^{18}$ Pursuant to Article 168(7) of TFEU, Member States are responsible for defining health policy and organizing and providing health services and healthcare. In this context, the determination of obligations of a service of general economic interest is firstly a matter of the Member States. The same definition of competences on a general level can be found in Article 14 of TFEU which provides that, given the place occupied by services of general economic interest in the shared values of the Union as well as their role in promoting social and territorial cohesion, the EU and the Member States, each within their respective powers and within the scope of application of the Treaty, are to take care that such services operate on the basis of principles and conditions which enable them to fulfil their missions. ${ }^{19}$ In cases FFSA vs. Commission [C-174/97, 100], Olsen vs. Commission [T-17/02, 216] and BUPA [T-289/03, 169] the Court of justice of the European Union has taken the standpoint that its competence in defining services of general economic interest is limited to checking whether the Member State has made a manifest error when defining the service as an service of general economic interest. ${ }^{20}$

16 Case BUPA [T-289/03, 165].

17 Member States' wide margin of discretion in defining the activities was confirmed also by the Court of Justice of the European Union in the case of FFSA and others vs. Commission [T 106/95, 99]. This standpoint may also be found in the Services Directive 1(3) and numerous European Commission documents: Communication from the Commission on the application of the European Union State aid rules to compensation granted for the provision of services of general economic interest, 2012/C 8/02, Point 46; Communication from the Commission: Services of General Interest in Europe (96/C281/03) OJ C 281/3, section 26; Communication from the Commission: White Paper on Services of General Interest, Brussels, 12 May 2004, COM(2004) 374 final, pp. 5-6; Green Paper on Services of General Interest, COM(2003) 270, section 30-32, etc.

18 See Articles 2(5), 6, 153 and 168(1), (7) TFEU.

19 Case BUPA [T-289/03, 167].

20 Such standpoint was also taken by the European Commission in Communication from the Commission on the application of the European Union State aid rules to compensation granted for the provision of services of general economic interest, 2012/C 8/02, point 46. 
Despite the fact that Member States have wide discretion, they need to be vigilant and ensure that the activity in circumstances of a given case fulfils the lowest criteria determined by the case-law of the Court of justice of the European Union, which are common to all services of general economic interest. When Member States wish to define an activity as service of general economic interest, they need to demonstrate: (i) economic nature of the activity, (ii) activity is carried out in the public interest ${ }^{21}$, (iii) the existence of the act of public authority which explicitly entrusts operator with the mission of service of general economic interest (act of public authority must contain a clear definition of SGEI obligations) and (iv) universal and compulsory nature of the entrusted mission. If the state fails do so, this may present a manifest error that has to be sanctioned by the European Commission. Further on we analyse the criteria for defining a service of general economic interest and in this perspective assess Slovenian complementary health insurance.

Figure 2: Criteria for defining an activity as service of general economic interest

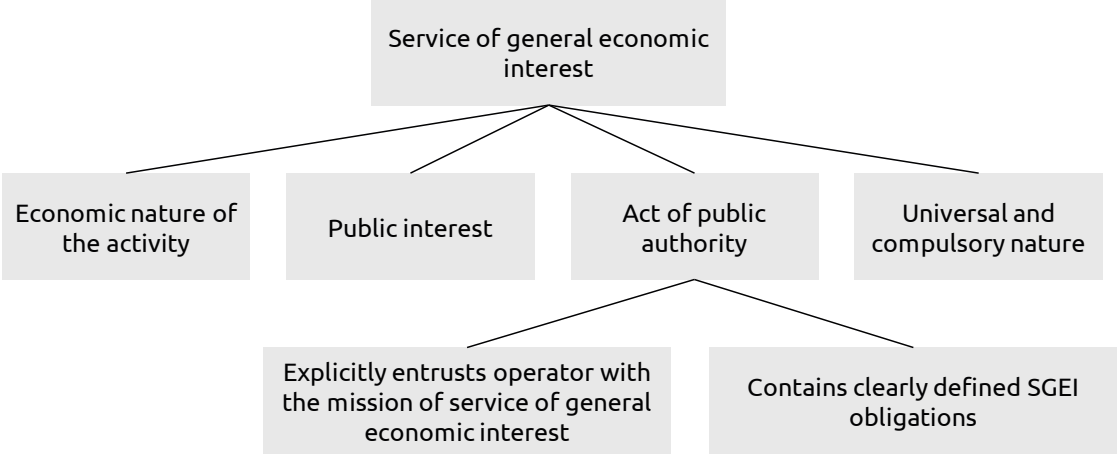

Source: author's.

\section{Does Slovenian Complementary Health Insurance Meet the Criteria for the Definition of the Activity as a Service of General Economic Interest?}

In order to define Slovenian complementary health insurance as a service of general economic interest, one has to demonstrate that the activity meets the criteria presented in Figure 2.

\section{a) Economic nature of the activity}

The Court of Justice of the European Union defines the nature of activity as economic, if it meets two criteria: first, the activity offers goods and

21 The state is obliged to set out the reasons why it considers that the service in question should be, due to its particular significance, defined as a service of general economic interest and thus separated from other economic activities. See Case BUPA [T-289/03, 172] and Case Merci Convenzionali Porto di Genova [C-179/90, 27]. 
services on the market ${ }^{22}$, and second, financial risk in performing the activity is borne by the subject that carries out the activity (offers goods or services on the market). ${ }^{23}$ This is not to say that the subject is obliged to carry out the activity in a profitable manner, ${ }^{24}$ but the fact that it can be carried out in such manner, at least on principle, suffices (Hatzopoulos, 2011, pp. 18-19). ${ }^{25}$ Slovenian complementary health insurance system is an activity carried out by health insurance companies on commercial principles and for the purposes of profit. This activity meets both criteria as health insurance companies offer complementary health insurance on market and at the same time bear financial risk in performing this activity. By both criteria being met, we can undoubtedly confirm that complementary health insurance is of economic nature.

\section{b) General or public interest}

In order to define the activity as a service of general economic interest, it has to be demonstrated that offering or carrying out the service is in the general or public interest. In Article 62 of Zakon o zdravstvenem varstvu in zdravstvenem zavarovanju (hereinafter ZZVZZ) ${ }^{26}$ the legislator defined that complementary health insurance represents the public interest of the Republic of Slovenia as it, together with compulsory health insurance, forms a social security system. The mere fact that national legislator in the general interest and within the broader sense defines a special legal regime for carrying out a certain activity, is in principle not imperative for the existence of service of general economic interest. ${ }^{27}$ It needs to be demonstrated in fact that carrying out of the activity is in the public interest.

Complementary health insurance is inseparable and essential element of social security system and it, as such, pursues identical objectives as compulsory health insurance does - financial security of the population against high healthcare expenses and appropriate and fair access to efficient and quality medical services. Without complementary health insurance, financial security against high healthcare expense and appropriate access to efficient and quality medical services seem an unattainable ideal. Public interest

22 Case Cisal and INAIL [C 218/00, 23].

Purchase of goods or services on the market does not define the (economic) nature of this activity per se. For the purpose of determination of the activity, account should be taken of the subsequent use of the purchased goods as the nature of the purchasing activity is determined also according to the economic or non-economic nature of subsequent use (FENIN [C-205/03, 26]).

23 Case Wouters [C-309/99, 48-49].

24 Case FFSA [C-244/94, 21].

25 Case SAT Fluggesellschaft mbH vs. Eurocontrol [C-364/92, 9]. For more information on interpretation of the second criterion, which is very extensive (actual competition is not required as alleged competition is sufficient in itself) see Sauter W. and Schapel H.: State and Market in EU Law: The Public and Private Spheres of the Internal Market before the EU Courts (Cambridge: CUP, 2009), p. 82.

26 Zakon o zdravstvenem varstvu in zdravstvenem zavarovanju (Health Care and Health Insurance Act) (ZZVZZ), Official Gazette of the RS, no. 9/1992.

27 See case BUPA [T-289/03, 178]. 


\section{Bruno Nikolić}

of complementary health insurance is affirmed also by its strong social function, which is reflected through the following arguments:

(i) complementary health insurance is an important and indispensable source of financing of healthcare system;

(ii) high level of complementary health insurance population coverage;

(iii) purpose of creation and nature of complementary health insurance.

i) Complementary health insurance as an important and indispensable source of financing of healthcare system

In 2011, private resources in financing of healthcare system amounted to $€ 841.743 .000$, representing $26.3 \%$ of total healthcare expenditure. In the same year, resources from voluntary health insurances amounted to $€ 422.000 .000$, representing a little over $50 \%$ of all private resources (ZZZS 2013, 144). The lion's share of these resources represent resources from complementary health insurance, which in 2010 accounted for about $€ 400.000 .000$, representing well beyond $90 \%$ of all resources from voluntary health insurances (Šik, 2011, p. 41). ${ }^{28}$ Within the EU, such a large share of voluntary or complementary health insurances in financing of healthcare can be found only in France. Alongside considerable share of funds (around 13\% of all healthcare expenditure), which indicates an exceptionally important role of complementary health insurance in the healthcare system, this insurance also bears the burden of covering expenses of medical inflation and inefficacy of public financing of healthcare.

The fact that the total contribution rate of compulsory health insurance has not changed since 2002 shows that the cost of medical inflation has been passed on to complementary health insurance. Medical inflation rate is normally above the percentage point of general inflation. In the period between January 2003 and March 2014 the general inflation was $34.2 \%$. Management decisions of insurance undertakings which provide complementary health insurance additionally point to the compensation of medical inflation. ${ }^{29}$ Between 2007 and 2014, Zavarovalnica Triglav raised the complementary health insurance premium from $€ 20.61$ to $€ 29.42$, which represents an increase of 42.7\%. Between 2006 and 2014 Adriatic Slovenica raised premiums from €20.71 to €29.38, representing an increase of $41.8 \% .^{30}$ Although in Slovenia data on medical inflation are not available for this period, the raises in premiums are consistent and, as is to be expected, exceed the general inflation rate. Both health insurance companies justified the gradual raising of premiums mainly by increasing

28 In the same year complementary health insurance covered loss events amounting to almost $€ 370.000 .000$. For more information on high claims percentage of complementary health insurance, which in 2006 amounted around 88\%, see Milenkovič Kramer, 2009.

29 We cannot claim that complementary health insurance bore the entire burden of medical inflation, as the latter caused also negative profits of health insurance fund and increase of out-of-pocket payments of health service users.

30 General inflation between 2006 and 2014 was $20.4 \%$. 
health services costs and changing the coverage ratio of compulsory health insurance benefits. Absorbing the costs of medical inflation is increasing the importance of complementary health insurance and, in line with this, achieving the social objective - it helps to maintain viability of compulsory health insurance financing as well as efficiency and quality of medical services which are covered by compulsory health insurance.

Economic crisis and recession that followed brought visible changes to the field of healthcare financing. The legislator and Zavod za zdravstveno zavarovanje Slovenije (Health Insurance Institute of Slovenia; hereinafter ZZZS) - provider of compulsory health insurance have reached for a shortterm strategy in order to solve financial problems of health insurance fund, which does not eliminate structural deficiencies but only mitigates the pathological problems and simultaneously deepens the scope of the deficiencies. Austerity measures, which reflect over-indebtedness of the country and health insurance fund alongside with passing the financial burden from public sources of financing to private ones both represent the central part of the strategy, the objective of which is ensuring financial sustainability of the healthcare system. Passing on the financial burden of over-indebted health insurance fund onto the private financing sources, mainly onto the complementary health insurance, is a consequence of increasing statutory user charges for benefits covered by compulsory health insurance. ${ }^{31}$ In doing so the state in the short term passed on financial burden and social responsibility on health insurance companies, which by a quick increase of insurance premiums passed them on the population. ${ }^{32}$ By increasing statutory user charges covered by complementary health insurance, the state additionally amplifies its role and significance in healthcare system.

\section{ii) High level of complementary health insurance population coverage}

At the end of 2012, 2,076,273 insured persons were provided with compulsory health insurance, $1,536,876$ of which were insured persons and 539,397 their dependent family members (ZZZS, 2013, p. 18). ${ }^{33}$ In 2012, complementary health insurance was on average taken out by 1,431,951 insured persons (Gracar, 2014, p. 14). Because some individuals do not need to obtain a complementary health insurance as they have statutory user charges for benefits covered by compulsory health insurance covered by other sources

31 For additional information on changes in legislation and measures taken by ZZZS on the basis of the legislative reforms see ZZZS (2012, pp. 20-21).

32 An excellent example of such practice is adoption of a Fiscal Balance Act (ZUJF) (OG RS, No. 40/12). Because of the reduction of percentage share of benefits covered by compulsory health insurance, which was a consequence of the adoption of the above mentioned Act, a monthly premium of all three insurance companies were increased on 1 July 2012 by $15-20 \%$.

33 According to Statistical Office of Republic of Slovenia (SURS), on 1 October 2012 Slovenia had a total population of $2,058,123$. This confirms almost complete compulsory health insurance population coverage. 


\section{Bruno Nikolić}

(state budget, ${ }^{34}$ compulsory health insurance ${ }^{35}$ ), the complementary health insurance coverage is very large. A good evidence of this is also the small difference between compulsory and complementary health insurance (approximately 105,000 persons). According to SURS and Ministry of Labour, Family, Social Affairs and Equal Opportunities in October 2012 Slovenia had 363,442 inhabitants under the age of 18 and 45,734 recipients of social assistance. The sum of minors, social assistance recipients and persons with complementary insurance amounts to more than $1,800,000$ persons. If we add pupils and students in regular education between the ages of 18 and $26^{36}$ and other sectors of the population which have statutory user charges covered by the state budget, we come fairly close to compulsory health insurance coverage. Thus we substantiate the claim that complementary health insurance covers almost all population of Slovenia. Extremely high complementary health insurance coverage is characteristic for all states in which users can take out complementary health insurance for statutory user charges (France, Belgium, Luxembourg) (Mossialos \& Thomson, 2009, p. 27). Very large coverage additionally confirms its important role in the social security system and at the same time demonstrates its strong social function.

\section{iii) Purpose of creation and nature of complementary health insurance}

Purpose of creation and nature of complementary health insurance have a strong social connotation. Healthcare financing system is based on compulsory health insurance, which does not cover all medical services. ${ }^{37}$ The compulsory health insurance coverage ratio also differs according to the group of services to which individual service belongs. Only a handful of medical services are fully covered, for all other services the insured person has to go directly to the service provider. Statutory user charge rate varies between 10 and 90\% of medical service value. Due to the high prices of medical services, some statutory user charges may be so high that can be classified as "catastrophic" health expenditure. According to Vzajemna, amounts of some statutory user charge in the first half of 2013 reached the following values: the highest

34 This title covers the statutory user charges for (Articles 24 and 25 of ZZVZZ):

- pre-trial prisoners not insured under other title, convicts serving a prison sentence and juvenile detention, minors awarded into a re-education facility, persons with imposed security measures of compulsory psychiatric treatment and care in a health establishment and compulsory treatment of alcoholism and drug addiction;

- insured persons and covered family members who do not have full compulsory health insurance coverage for payment of medical services if they fulfil the conditions for granting financial social assistance, which is determined by Social Work Centre;

- war disabled;

- war veterans;

- victims of war violence.

35 This title covers the surcharge for:

- children, pupils and students in regular education (until the individual reaches the age of 18 or in case of regular education the age of 26);

- children and adolescents with physical and mental health disabilities;

- children and adolescents with accident-related head injury and brain injury.

36 In academic year 2011/2012 in Slovenia there were 89,600 students enrolled in higher education study programmes at universities and independent higher education institutions (SURS).

37 For covered medical services see Article 23 of ZZVZZ. 
statutory user charge for the medicine from the intermediate list $(90 \%$ of this medicine's value is covered by statutory user charge) was $€ 9,579.11$; average statutory user charge for treatment at a health resort was €832 while the most expensive amounted to $€ 4,560$; the highest single statutory user charge for most demanding medical services, needed by more than 8,000 insured persons (complementary statutory user charge covers $10 \%$ of their value), was $€ 21.560$ (Mikeln, 2014). ${ }^{38}$ Introduction of high statutory user charge and large financial risk that they bring in cases of healthcare needs, resulted in the creation of complementary health insurance market and its flourishing. Due to extremely high statutory user charge the individuals, except for those more susceptible to health risk, are compelled to take out complementary health insurance, as they otherwise run the risk of "catastrophic" health expenditure. The nature of complementary health insurance and regulation of statutory user charge make clear that complementary health insurance does not have a role of upgrading social and health security but it represents integral and key element of Slovenian social security system. It is also difficult to claim that taking out complementary health insurance is a consequence of autonomous individual's decision, as the height of statutory user charge renders individual's free will almost impossible. This is also supported by high level of insurance coverage of the population.

Given a strong social function of complementary health insurance, its role and importance in the healthcare and social security system, one can conclude that performance of this activity is in the public interest.

c) Act of public authority that explicitly entrusts operator with the mission of service of general economic interest and clearly defines service of general economic interest obligations

Recognition of service of general economic interest mission does not necessarily presume that the operator entrusted with that mission will be given an exclusive or special right to carry it out. There is a distinction between a special or exclusive right conferred on an operator and the service of general economic interest mission which, where appropriate, is attached to that right. The grant of a special or exclusive right to an operator is merely the instrument, possibly justified, which allows that operator to perform service of general economic interest mission. ${ }^{39}$ Assigning the mission of general economic interest thus does not demand granting a special or exclusive

38 For illustration of the height of statutory user charges and financial risk they bring along, we present an example of an average monthly salary and time period in which an individual dedicates the amount of the highest single statutory user charges for most demanding medical services to healthcare: employed individual who receives an average monthly salary (in February 2014 average gross salary was $€ 1,520.88)$, would need a little more than 14 years to spent $€ 21,560$ on healthcare (compulsory and complementary health insurance contributions - we considered Vzajemna's insurance premium value, which in March 2014 totalled €27.62). This calculation takes into account only the contribution of compulsory health insurance, which is charged to the employee directly (6.36\% of gross salary). If the calculation considers also the employer's contribution, the time period would be reduced to a little less than 8 years.

39 See case BUPA $[\mathrm{T}-289 / 03,179]$. 


\section{Bruno Nikolić}

right because an act of public authority, which clearly defines obligations to one or even all operators who perform certain service, suffices. ${ }^{40}$ ZZVZZ represents such an act of public authority. It created and defined a service of complementary health insurance. Economic operators have to perform services while respecting the special obligations laid down in the Articles 62-62c ZZZVZ (community rating, open enrolment and lifetime cover). Article 62.b, Рar. 1, Point 4 of ZZVZZ further defines the subject and health care benefits covered by complementary health insurance which is difference between the value of health services in accordance with Article 23 of ZZVZZ and the share of these value covered by compulsory health insurance under the same Article, or a part of this difference, when statutory user charges refer to the right to medications with the highest recognised efficacy and medicinal devices. Legislator does not define only obligations for minimum benefits ensured that the products proposed would respect certain minimum quality standards, but defines the subject of complementary health insurance and its benefits entirely, as complementary health insurance by the law may not include additional services or benefits. ${ }^{41}$ For this purpose a health insurance company may create a supplementary health insurance which represents a separate category of voluntary insurances. Furthermore, Point 2 of Article 62(1) of ZZVZZ obliges the complementary health insurance providers to participate in the equalization scheme for complementary health insurance, which distributes fairly some of the differences that arise in insurers' costs due to the differences in age and gender of the insured persons.

In case BUPA the Court of Justice of European Union was deciding whether Health Insurance Acts, which specify obligations of a private health insurance (community rating, open enrolment, lifetime cover and minimum benefits), could be considered as an act of public authority that explicitly entrusts operator with the mission of service of general economic interest with clearly defined obligations. The answer of the Court was affirmative. ${ }^{42}$ Drawing on the basis of the comparison between the Irish regulation of private health insurance (Health Insurance Acts) and Slovenian regulation of complementary health insurance (ZZVZZ) we may conclude that Slovenian complementary health insurance also meets required criterion. Regulation of both countries, within the meaning of obligations imposed by Irish Health Insurance Acts and Slovenian ZZZV, coincide almost entirely: community rating, open enrolment, lifetime cover and level of benefits received by insured people, where the Slovenian regulation is even stricter, because it does not define only minimum level of benefits, but a complete extent of benefits provided by complementary health insurance. In view of the above, it can be concluded that in case of Slovenian complementary health insurance an act of public

40 See cases Almelo [C-393/92, 47] and BUPA [T-289/03, 179-182].

41 Irish legislation imposes on the operators who provide private health insurance the obligation of minimum benefits.

42 See case BUPA [T-289/03, 174-176 and 182]. 
authority-ZZVZZ which explicitly entrusts operator with the mission of service of general economic interest with clearly defined obligations is presented.

\section{d) Universal and compulsory nature of the service of general interest mission}

Universal nature of the service does not demand that the service is universal in narrow meaning. ${ }^{43}$ The fact that only relatively limited group of users benefits from the service does not necessarily call into question the universal nature of the service's mission (in our case complementary health insurance). ${ }^{44}$ The universal nature also does not require that complementary health insurance is free of charge and it has to be offered irrespective of economic profitability. Population's not covered by this service due to the insufficiency of financial means does not undermine its universal nature. It suffices that the service is offered to the entire population at an affordable price and on similar quality conditions. ${ }^{45}$ Likewise, universal nature does not oppose free fixing of the amount of insurance premiums. Insurance premiums аге in Slovenia determined by the health insurance companies (market forces), which might lead to high premiums and diminished accessibility of health care. Due to the obligations of community rating, and competition between the providers of complementary health insurance, the risk of high premiums is very limited. ${ }^{46}$ Despite the limited risk, the prices of premiums have increased sharply during the last years in Slovenia. ${ }^{47}$ The representatives of health insurance companies point out that the prices are dangerously approaching the psychologically highest acceptable amount of €30. However, the increase of insurance premiums is not a consequence of "non-functioning" market mechanisms or even service of general economic interest obligations, but of the state policy which aims to relieve public sources of funding by passing financial burden of financing health care to private sources (complementary health insurance).

Compulsory nature of complementary health insurance is a prerequisite for the existence of a mission of service of general economic interest as well. That compulsory nature must be understood as meaning that the operators entrusted with the service of general economic interest mission by an act of a public authority are, in principle, required to offer the service in question on the market in compliance with the service of general economic interest obligations which govern the supply of that service. Operators who perform service of complementary health insurance in Slovenia are not entitled to any special or exclusive right which would impose performing of this service irrespective of the costs of performing it. Nevertheless, the ZZVZZ, which explicitly entrusts the operators with the mission of service of general

43 Characteristic for compulsory health insurance.

44 The Court of Justice of the European Union confirmed this view in case BUPA [T-289/03, 187].

45 See case BUPA $[\mathrm{T}-289 / 03,206]$.

46 See case BUPA [T-289/03, 202-203].

47 With the exception of 2014 when all three health insurance companies lowered their premiums: Vzajemna from $€ 27.76$ to $€ 26.79$, Triglav from $€ 28.54$ to $€ 27.51$ and Adriatic Slovenica from €28.34 to €27.49. 


\section{Bruno Nikolić}

economic interest, also establishes the subject's obligation to offer the service to everyone upon their request. In case BUPA the Court of Justice of the European Union took a position that compulsory nature of the service and subsequently the mission of service of general economic interest exist, if the service-provider is obliged to contract, on consistent conditions, without being able to reject the other contracting party. ${ }^{48}$ To confirm the condition of compulsory nature of service of general economic interest, the obligation of open enrolment given in Article 62.b(1) of ZZVZZ suffices. Compulsory nature of the service is additionally supported by other complementary health insurance obligations which limit the discretion of health insurance companies: community rating, lifetime cover and level of benefits provided by complementary health insurance. ${ }^{49}$

Voluntary nature of complementary health insurance, in the meaning that the decision for taking out insurance is left to the insurer's freedom of choice, is not contrary to the universal and compulsory nature of the service. ${ }^{50}$ Furthermore, in favour of universal and compulsory nature of complementary health insurance implies also high insurance coverage of the population. Around $70 \%$ of the population takes out the insurance directly through contractual relation with one of the insurers. Adding the rest of population which has complementary health insurance covered by other statutory source, the percentage share is almost the same as the share of compulsory health insurance coverage.

In case BUPA the Court of Justice of the European Union was also evaluating, in the context of universal and compulsory nature of the service, the initial waiting period after which the insurance enters into force, which is an integral part of the Slovenian complementary health insurance regulation (Article 62.b(1), Point 5 of ZZVZZ). The Court took the view that the waiting periods present an essential element of voluntary health insurance based on the obligation of community rating and open enrolment. Despite the fact that waiting periods impose a restriction on taking out insurance, they are essential and lawful measures designed to prevent abuse consisting in obtaining purely temporary cover in order to obtain treatment rapidly without having contributed beforehand, by paying premiums. ${ }^{51}$

On the basis of Court of Justice of the European Union, which in the case of an Irish private health insurance (case BUPA) decided that the universal and compulsory natures of the mission of service of general economic interest exists $^{52}$, and on the basis of comparative analysis of Slovenian complementary health insurance regulation it can be concluded that in the latter case universal

\footnotetext{
48 See case BUPA [T-289/03, 186-190].

49 See case BUPA [T-289/03, 191-192].

50 See case BUPA $[T-289 / 03,190-195]$ and related case law.

51 See case BUPA [T-289/03, 195-200].

52 See case BUPA [T-289/03, 205-207].
} 
and compulsory natures of the mission of service of general economic interest exist as well.

\section{Conclusion}

Inlightofcriteria for defining anactivityasaservice of generaleconomicinterest, laid down by the Court of Justice of the European Union, the assessment of Slovenian complementary health insurance demonstrates compliance with all criteria required. Complementary health insurance has an economic nature and is performed in the public interest as an indispensable part of healthcare system (social security). Further analysis confirms both, existence of the act of public authority which explicitly entrusts operator with the mission of service of general economic interest whose obligations are clearly defined (ZZVZZ) and compulsory and universal nature of complementary health insurance. It can be concluded that Slovenian complementary health insurance is a service of general economic interest which falls under a limited scope of the Union acquis (rules on internal market and competition law). This definition does not justify any regulatory state intervention regarding this activity (e.g. direct or indirect allocation of state resources to subjects providing services of general economic interest - compensation for public services, different obligations of complementary health insurance, rules providing solvency of health insurance providers etc.) but only provides an opportunity for their justification, which is the next step in the assessment of compatibility between statutory rules of Slovenian complementary health insurance and the EU acquis.

Bruno Nikolic, Teaching Assistant in the field of Constitutional regulation and Legislative Regulation of the EU at the Faculty of Administration (University of Ljubljana, Slovenia). Areas of research interest: Constitutional law, Law and Economics of the EU, Healthcare regulation, Financing of Healthcare systems. 


\section{References}

Adriatic Slovenica d.d. (2012). Splošni pogoji dopolnilnega zdravstvenega zavarovanja.

Brezovnik, B. (2008). Izvajanje javnih služb in javno-zasebno partnerstvo. Maribor: Založba Lex localis.

Damjanovic, D., \& de Witte, B. (2009). Welfare values and welfare integration under the Lisbon Treaty. In U. Neergaard, L. Roseberry \& R. Nielsen (Eds.), Integrating welfare functions into EU law: From Rome to Lisbon (pp. 53-94). Copenhagen: DJØF Publishing.

European Commission. (2001). Communication from the Commission - Services of general interest in Europe (2001/C 17/04, of 19. 1. 2001).

European Commission. (2007). Communication from the Commission to the European Parliament, the Council, the European Economic and Social Committee and the Committee of the RegionsAccompanying the Communication on "A single market for 21st century Europe" Services of general interest, including social services of general interest: a new European commitment, of 20.11. 2007.

European Commission. (2010). Guide to the application of the European Union rules on state aid, public procurement and the internal market to services of general economic interest, and in particular to social services of general interest (SEC(2010) 1545, of 7. 12. 2010).

European Commission. (2011). Commission Decision on the application of Article 106(2) of the Treaty on the Functioning of the European Union to State aid in the form of public service compensation granted to certain undertakings entrusted with the operation of services of general economic interest (2012/21/EU, of 20. December 2011).

Gracar, I. ( 2014). Spremembe financiranja sistema zdravstvenega varstva RS, predlog z dne 24. 2. 2014.

Hatzopoulos, V. (2011). The concept of 'economic activity' in the EU Treaty: from ideological dead-ends to workable judicial concepts. Research papers in Law 06/2011. College of Europe, Department of European Legal Studies.

Mikeln, A. (2014). Pomen zasebnih sredstev za dolgoročno stabilnost zdravstvenega sistema. Prispevek na posvetu Zdravstvena polemika: Kakšna bo cena vašega zdravja v prihodnje. Ljubljana.

Milenkovič Kramer, A. (2009). Private health insurance in Slovenia: a study for the European Commmission.

Mossialos, E., \& Thomson, S. (2009). Private health insurance in the European Union. Final report prepared for the European Commission, Directorate General for Employment, Social Affairs and Equal Opportunities. LSE Health and Social Care, London School of Economics and Political Science.

Neergaard, U. (2013). The Concept of SSGI and Asymmetries Between Free Movement and Competition Law. In U. Neergaard, E. Szyszczak, J. W. van de Gronden \& M. Krajewski (Eds.), Social services of general interest in the EU - Legal issues of services of general interest (pp. 205-245). The Hague: TMC Asser Press. DOI: 10.1007/978-90-6704-876-7_9

Pečarič, M., \& Bugarič, B. (2001). Javne službe. Ljubljana: Fakulteta za upravo. 
Szyszczak, E. (2013). Soft Law and Safe Havens. In U. Neergaard, E. Szyszczak, J. W. van de Gronden \& M. Krajewski (Eds.), Social services of general interest in the EU-Legal issues of services of general interest (pp. 317-345). The Hague: TMC Asser Press. DOI: 10.1007/978-90-6704-876-7_13

SURS - Statistični urad RS. (2013). Izdatki za zdravstveno varstvo po namenih in virih financiranja, Slovenija, 2003-2012.

Šik, A. (2011). Obratovalni stroški dopolnilnega zdravstvenega zavarovanja. V: Dopolnilno zdravstveno zavarovanje in zdravstvena reforma. Ljubljana: Slovensko zavarovalno združenje.

van de Gronden, J. W. (2013). Free Movement of Services and the Right of Establishment. Does EU Internal Market Law Transform the provision of SSGI?. In U. Neergaard, E. Szyszczak, J. W. van de Gronden \& M. Krajewski (Eds.), Social services of general interest in the EU-Legal issues of services of general interest (pp. 123-160). The Hague: TMC Asser Press.

DOI: $10.1007 / 978-90-6704-876-7 \_6$

ZZZS - Zavod za zdravstveno zavarovanje Slovenije. (2012). Poslovno poročilo za leto 2011. Ljubljana: Zavod za zdravstveno zavarovanje Slovenije.

ZZZS - Zavod za zdravstveno zavarovanje Slovenije. (2013). Poslovno poročilo za leto 2012. Ljubljana: Zavod za zdravstveno zavarovanje Slovenije. 